http://jurnal.fkip-uwgm.ac.id/index.php/Script

Script Journal: Journal of Linguistic and English Teaching

P-ISSN: 2477-1880; E-ISSN: 2502-6623

October 2017, Vol. 2 No.2

\begin{tabular}{|l|l|l|}
\hline Received: September 2017 & Accepted: September 2017 & Published: October 2017 \\
\hline
\end{tabular}

Article DOI: http://dx.doi.org/10.24903/sj.v2i2.133

\title{
English Standar Kompetensi, Kompetensi Dasar, \&Ujian Nasional of SMA in Revised Bloom`s Taxonomy
}

\author{
Putri Kamalia Hakim \\ Singaperbangsa Karawang University \\ putrikamaliahakim@gmail.com
}

\begin{abstract}
This study was conducted to investigate the coverage of Revised Bloom's taxonomy in the English Standar Kompetensi (SK), Kompetensi Dasar (KD) and the English test items of UjianNasional for SMA. Content analysis method was chosen as the research design for this study. The writer analyzed the data by categorizing the verbs and the nouns of the data in relation to the categories and dimension of Revised Bloom's Taxonomy. The results of this study revealed that $53 \%$ of SKs and KDs cover Understand category and the rest cover Analyze category. All of the SKs and KDs cover conceptual knowledge and other knowledge dimensions are not covered. Moreover, the coverage of Revised Bloom's Taxonomy in English test items of UjianNasional for SMA is not aligned with the coverage of Revised Bloom's Taxonomy in English SK and KD. The SKs and KDs only cover Remember, Understand, Apply and Analyze categories while the test items were associated with Remember, Understand, Apply, Analyze, and Evaluate categories.More than $90 \%$ of English test items of UjianNasional for SMA only covered low order of cognitive categories (Remember, Understand, and Apply). Most of the test items covered factual knowledge and the rest of them covered conceptual knowledge and none of them covered procedural and metacognitive knowledge.
\end{abstract}

Keywords: revised Bloom`s taxonomy, national exam, Englishtest item 


\section{INTRODUCTION}

Indonesia has long-term program, Rencana Pembangunan JangkaPanjangPendidikanNasional, to develop national education which is expected to guide Indonesian people to be intelligent and competitive in the year 2025 (DepartemenPendidikanNasional, 2005). The target forces Indonesian government to improve education quality. One of the strategies used to improve education quality by the government is making an evaluation program through national examination. Having national examination as the evaluation program means that national examination should be carefully designed so that those who pass the national examination can represent the improvement of national education which further will create intelligent and competitive graduates.

National examination, well known as Ujian Nasional (UN) is used to assess graduate competences nationally. In Naskah Akademik Kurikulum Tingkat Satuan Pendidikan Jenjang Pendidikan Dasar Dan Menengah published by Departemen Pendidikan Nasional (2007), it is stated that Standar Kompetensi (SK) and Kompetensi Dasar (KD) are national minimum standard competences to be achieved by students to graduate from a school. Therefore, SK and KD are competences that will be assessed through UN.

In relation to improve national education to create intelligent and competitive graduates, assessment technique which is appropriate to the aims of the curriculum and used to improve students thinking level should be designed and implemented. The high level questions should be designed in national examination in order that students who can pass national examination are those who can utilize their high order thinking level. Revised Bloom`s Taxonomy (RBT) is one of the criteria need to be considered while designing and preparing such assessment technique. The Revised Bloom's Taxonomy is clearer and less confusion about the fit of a specific verb or product to a given levelthan the original taxonomy because it has 19 subcategories and two-dimensional organization. The revised versioncame with some comprehensive additions of how the taxonomy intersects upon different types of knowledge. Many changes have occurred in educational society over the last five decades; the Revised Bloom's Taxonomy fits today teachers' needs. Anderson, et.al (2001) in revising the original Bloom's Taxonomy have sought to revise and extend their approach, use common language, be consistent with a current psychological and educational thinking, and provide realistic examples of the use of the framework.

Referring to those explanations, this research aims to observe the coverage of Revised Bloom's Taxonomy categories and dimensions in English SK and KD and the English test 
items of UjianNasional for Senior High School (SMA). The order of thinking processes and types of knowledge required in the test items English UjianNasional will be compared to those required in English SK and KD. We will see how English test items of UjianNasional cover categories and dimensions of the Revised Bloom's taxonomy and whether the coverage in line with coverage of revised Bloom's taxonomy categories and dimensions in English SK and KD.

\section{METHODOLOGY}

This study was conducted through qualitative research focusing on the content analysis method. As stated by Flick (2007) in Boyd (2009, p.3) that qualitative research is used:"to understand, describe and sometimes explain social phenomena from theinside in a number of different ways.” It is done by analyzing documents (texts, images, film or music) or similar traces of experiences or interactions. This study was done by analyzing KTSP document and English UjianNasional document including the cassette for listening section to investigate the coverage of Revised Bloom's taxonomy in the English SK, KD and the English test items of UN for SMA.

\section{Data and Data Source}

The data sources used in this study were documents of KTSP and documents of English UN including the cassettes of listening section. Documents of English UjianNasional 2008/2009 set A and English UjianNasional2009/2010 set A were used in this research. There are two sets document of English UjianNasional, set A and set B. Both sets have same test items, so by picking up set A the writer believed it can represent both sets. The data taken from KTSP document are all SKs and KDs in KTSP. The data taken from document of English UjianNasional are all English test items of UN for SMA 2008/2009 set A, and all English test items of UN for SMA 2009/2010 set A.

\section{Data Collection Procedure}

To collect all English test items of UjianNasional for SMA year 2008/2009 set A and UjianNasional for SMA year 2009/2010 set A, the writer took documents of English UN for SMA including the cassette of its listening section from SMA Negeri 1 Tambun Selatan. Then, the writer transcribed the listening section. The writer picked up fifty questions of two sections of English UN for SMA year 2008/2009 set A and fifty questions of two sections of English UN for SMA year 2009/2010 set A then tabulated them.To collect English SKs and KDs in KTSP, the writer took KTSP document from SMA Negeri 1 Tambun Selatan. Then 
the writer picked up each English SK and KD in KTSP; 12 SKs and 24 KDs from year X, 12 SKs and $24 \mathrm{KDs}$ from year XI, and $12 \mathrm{SKs}$ and $23 \mathrm{KDs}$ from year XII and tabulated them.

\section{Data AnalysisProcedure}

The data were analyzed through several steps. The first data, the test items, was analyzed through the following procedures: 1) Stating the intended outcome of each test item first. 2) Separating the verb and the noun phrase of each intended outcome. 3) Categorizing the verbs and the nouns in relation to the categories and dimension of Revised Bloom's Taxonomy. 4) Placing them into the Taxonomy Table 5) Calculating the number of test items which are placed in each category and dimensions.

The second data, the SKs and KDs, were analyzed through the following procedures: 1) Separating the verb and the noun phrase of each KD. 2) Categorizing the verbs and the nouns in relation to the categories and dimension of Revised Bloom's Taxonomy. 3) Placing them into the Taxonomy Table 4) Calculating the number of test items which are placed in each category and dimensions.

\section{FINDINGS}

The findings in this study were divided into two big categories. The first finding is to see how Revised Bloom's taxonomy covered in English test items of UN for SMA and the second finding is to the coverage of Revised Bloom's taxonomy in English SK and KD.

\section{The coverage of Revised Bloom's Taxonomy in English SK and KD}

There are seventy one KDs under thirty six SKs which were analyzed in this study. Twenty four KDs under 12 SKs for year X, twenty four KDs under 12 SKs for year XI, and twenty three under 12 SKs for year XII. Those SKs and KDs are designed to cover four major language skills to be taught to SMA students. The coverage of the cognitive process categories and knowledge dimensions of RBT in SKs and KDs for SMA are presented in the chart below. 


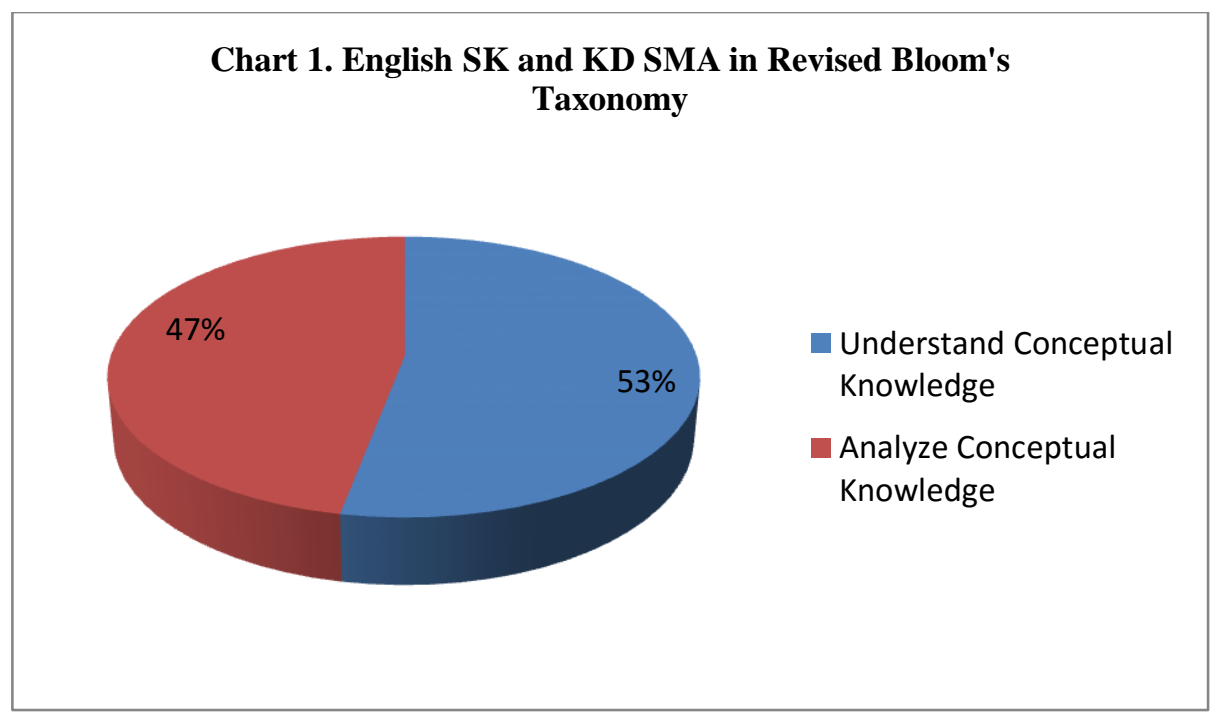

According to the chart above, we can see that $53 \%$ of SKs and KDs cover Understand category and the rest cover Analyze category. $53 \%$ of SKs and KDs which are associated with understand category requires students' receptive skill. $47 \%$ of the SKs and KDs which are associated with Analyze category require students' productive skill. All SKs and KDs for SMA students which deal with receptive skills are associated with Understand category because the verbs used to state the SK and KD are similar, Memahami and Merespon. The word Memahamiclosely related to Understandcategory and the word Merespon, according to KamusUmumBesarBahasa Indonesia, means memberikanrespons and respons means tanggapan, reaksiataujawaban. So, students are expected to be able to make reactions for spoken/written text that indicates they understand information on the texts.

The rest of SKs and KDs for SMA students which are dealing with productive skills are associated with Analyze category. The verb used is Mengungkapkanwhich the writer believes that is the verb associated with Analyze category. According to KamusUmumBesarBahasa Indonesia, Mengungkapkanmeans menunjukan (show), mengungkapkan (reveal), memaparkan (explain), or menguraikan (analyze). That verb requires remembering, understanding, applying, and analyzing process as well, so the writer believes those SKs and KDs are associated with Analyze category.In speaking, students are expected to express meanings in formal and informal transactional and interpersonal conversation, while in writing, students are expected to express meanings in certain functional texts, respond meanings and generic structure of monologue texts.

When it is said that the SK and KD cover Understand and Analyze category, it doesn't mean that SK and KD do not cover Remember and Apply, the categories lied between Understandand Analyze category. It is true that the Revised Bloom's taxonomy do not form a 
cumulative hierarchy. But Anderson (2001: 267) said that "the revised framework is a hierarchy in the sense that the six major categories of the cognitive process dimension are presumed to be ordered in terms of increasing complexity". So, the mastery of a more complex cognitive process category required prior mastery of the entire less complex categories that means the mastery of Analyze category required mastery of Remember, Understand, and Apply category.

In the aspect of knowledge domain, all of the SKs and KDs are considered required conceptual knowledge. If we take a look at the noun phrase stated in SKs and KDs, maknadalampercakapan, teksfungsionalpendekdan monolog, we can see that knowledge of information bits (meanings in conversations, functional text and monologue) are interconnected and how they are functioned together are required here. First, the students should be able to master facts in presented information then they should be able to understand the concept under those facts, how each part of presented facts functioned together.

\section{The coverage of Revised Bloom's Taxonomy in English test items of UjianNasional for} SMA

English test items of UjianNasional for SMA analyzed in this study are English test items of UjianNasional for SMA in the year 2008/2009 set A and English test items of UjianNasional for SMA in the year 2009/2010 set A. Both of them consist of fifty test items which are divided into two parts; fifteen test items for listening section and thirty five test items for reading sections. The coverage of the cognitive process categories and knowledge dimensions of Revised Bloom's Taxonomy in English test items of UjianNasional for SMA 2008/2009 set A is presented in the chart below.

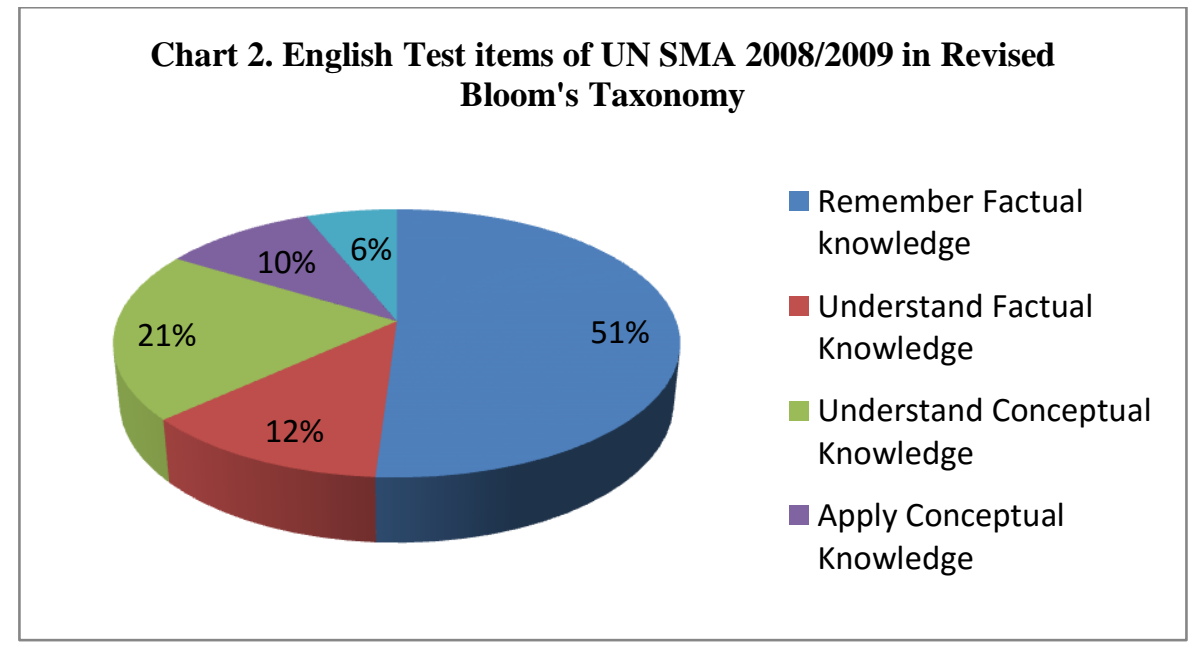


According to the chart above, we can see that more than $90 \%$ of English test items of UN for SMA year 2008/2009 only covered low order of cognitive categories (Remember, Understand, and Apply) and 6\% covered Analyze category. 63\% of the test items covered factual knowledge, $37 \%$ of them covered conceptual knowledge and none of the covered procedural and metacognitive knowledge. $51 \%$ of the test items for Remember factual knowledge, $12 \%$ for Understand factual knowledge, $21 \%$ for Understand Conceptual knowledge, 10\% for Apply conceptual knowledge, and $6 \%$ for Analyze factual knowledge.

$51 \%$ of the test items are under remember factual knowledge because they only ask students to mention detailed information in much as the same form as it was written/listened from spoken text in the form of conversation and descriptive, narrative, and report monologue, detailed information in written text in the form of letter, announcement, advertisement, narrative, report, recount, and discussion texts. $12 \%$ of the test items are under understand factual knowledge because they ask students to define a word, and to compare two paragraphs of discussion text. $21 \%$ of the test items are under understand conceptual knowledge because they ask students to state general theme of spoken text, written narrative text, written letter, advertisement, news item text, report text, and short message and to find out the message of a story. $10 \%$ of the test items are under apply conceptual knowledge because they ask students to make up an appropriate response of an expression given in some dialogues. $6 \%$ of the test items are under analyze conceptual knowledge because they ask students to find out the writer's intention and purpose in writing the texts.

In the aspect of knowledge dimension, thirty three test items here are considered required Factual Knowledge; some of them emphasized knowledge of terminology; the students were asked to have the knowledge that they need to define some vocabularies, and the rest of them emphasized knowledge of specific details and elements; those test items requires students' knowledge of specific facts in the presented information. The rest of the test items required conceptual knowledge, are under knowledge of principles and generalizations, knowledge of how facts in presented information interconnected and functioned together and used in determining appropriate action to be taken. They required the knowledge that students need to restate general theme, the purpose of the text, and make appropriate responses of an expressions.

The coverage of the cognitive process categories and knowledge dimensions of Revised Bloom's Taxonomy in English test items of UN SMA 2009/2010 set A is presented in the chart below. 


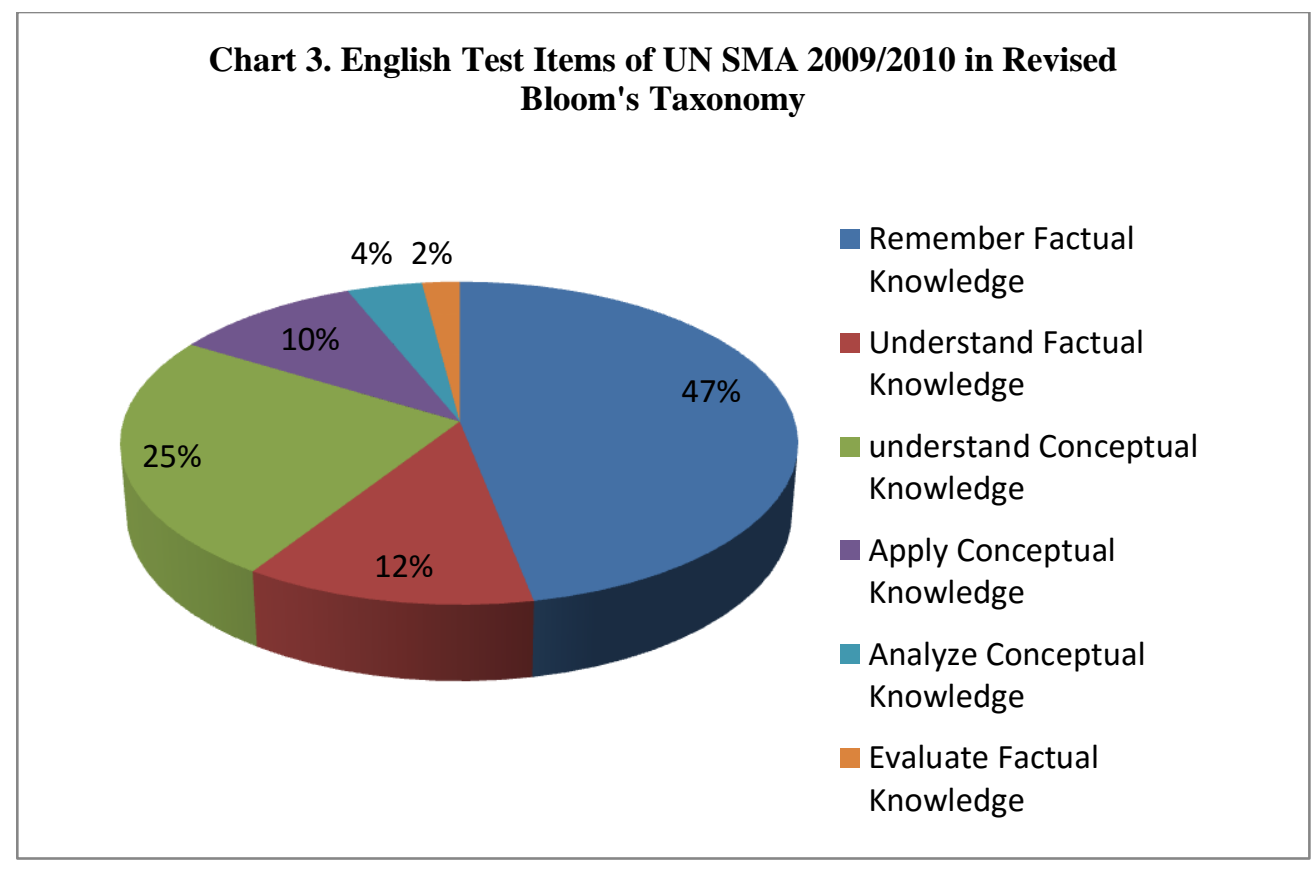

According to the chart above, we can see that more than $90 \%$ of English test items of UN for SMA year 2009/2010 only covered low order cognitive categories (Remember, Understand, and Apply) and 4\% covered Analyze category and 2\% covered Evaluate category. $47 \%$ of the test items are under remember factual knowledge because they ask students to $61 \%$ of the test items covered Factual knowledge, $39 \%$ of them covered conceptual knowledge and none of the covered Procedural and Metacognitive knowledge. $47 \%$ of the test items are Remember Factual knowledge, 12\% are Understand Factual knowledge, 25\% are Understand Conceptual knowledge, 10\% are Apply Conceptual knowledge, $4 \%$ are Analyze Factual knowledge, and 2\% are Evaluate Factual knowledge.

$47 \%$ of the test items are associated with Remember Factual knowledge because they ask students to find detailed information in spoken text in the form of conversation and report monologue, detailed information in written text in the form of letter, announcement, advertisement, narrative, news item, report, descriptive, explanation, and discussion texts. $12 \%$ of the test items are under Understand Factual knowledge because they ask students to infer meanings of some sentences, to define some words, and to compare two different paragraphs. $25 \%$ are under Understand Conceptual knowledge because they ask students to summarize ideas in some spoken and written texts, $10 \%$ of the test items are for Apply Conceptual knowledge because they ask students to make up an appropriate response of some expressions in given dialogues, $4 \%$ of the test items are for Analyze Factual knowledge because they ask students to find out the writer's purpose of writing texts, and $2 \%$ of the test 
items are for Evaluate Factual knowledge because they ask students to assess which of the choices is the most improbable reason in a discussion text.

The coverage of Revised Bloom's Taxonomy in English test items of UN SMA 2009/2010 is broader than the coverage of Revised Bloom's Taxonomy in English test items of UjianNasional for SMA 2008/2009. The test items year 2008/2009 covers four cognitive process categories; Remember, Understand, Apply, and Analyze, but the test items year 2009/2010 covers five cognitive process categories; Remember, Understand, Apply, Analyze and Evaluate, even there is only one test item that is considered under Evaluate category.

In the aspect of knowledge dimension, thirty test items here are considered required Factual Knowledge; some of them emphasized knowledge of terminology; the students were asked to have the knowledge that they need to define some vocabularies and select a picture of the terminology being talked, and the rest of them emphasized knowledge of specific details and elements; those test items requires students' knowledge of facts in the presented information. Other test items required conceptual knowledge. They are under knowledge of principles and generalizations, knowledge of how facts in presented information interconnected and functioned together and used in determining appropriate action to be taken. They required the knowledge that students need to restate general theme, the purpose of the text, and make appropriate responses of an expressions.

\section{DISCUSSION}

The findings shows that English test items of UjianNasional for SMA didn't cover all cognitive process categories and knowledge dimensions of the Revised Bloom's Taxonomy. We can see that more than $90 \%$ of English test items of UN for SMA year 2008/2009 and year 2009/2010 only covered low order of cognitive categories (Remember, Understand, and Apply). About $60 \%$ of the test items covered factual knowledge; about $37 \%$ of them covered conceptual knowledge and none of the covered procedural and metacognitive knowledge.

Comparing to the study by Ayvaci \& Turkdogan (2010), it revealed a close result. They found that majority of the questions asked in the examination papers required recall or memorizing ability, same with the test items analyzed here which shows that $83 \%$ of the test items required the first two cognitive process categories. Haryanti (2006) also reported similar result. She found that most of the questions in textbook used by biology teachers for junior high school student year VII dominated Remember and Understand level.

However, the coverage of Revised Bloom's Taxonomy in English test items of UN SMA year 2008/2009 is aligned with the coverage of Revised Bloom's Taxonomy in English 
SK and KD, even the proportion of each category is different. In fact, observing coverage of Revised Bloom's Taxonomy in English test items of UN for SMA year 2009/2010 let us see that there is inappropriateness of the coverage. The coverage of Revised Bloom's Taxonomy in English test items of UN for SMA 2009/2010 is broader than the coverage of Revised Bloom's Taxonomy in SK and KD. The highest category covered by SK and KD is Analyze category, but the test items year 2009/2010 covers five cognitive process categories; Remember, Understand, Apply, Analyze and Evaluate, even though there is one test item that is considered under Evaluate category.

By looking at the result, we can see that the minimum competencesto be achieved by the students to graduate from a school only require low order of cognitive categories. It means that to graduate from a high school, students do not have to master high level of thinking. Moreover, most of the test items of the English national examination also only asked the students to use low level of thinking. If Indonesia wants to create intelligent and competitive graduates, it is important to develop basic competences and test items which require high cognitive processes.

\section{CONCLUSION}

Based on the result of the research findings and the discussion, it can conclude that English test items of UjianNasional for SMA do not cover all cognitive process categories and knowledge dimensions of the Revised Bloom's Taxonomy. The test items were associated with Remember, Understand, Apply, Analyze, and Evaluate categories. More than $90 \%$ of English test items of UjianNasional for SMA only covered low order of cognitive categories (Remember, Understand, and Apply). Most of the test items covered factual knowledge and the rest of them covered conceptual knowledge and none of them covered procedural and metacognitive knowledge.

However, the coverage of Revised Bloom's Taxonomy in English test items of UjianNasional for SMA is not aligned with the coverage of Revised Bloom's Taxonomy in English SK and KD. The SKs and KDs only cover Remember, Understand, Apply and Analyze categories while the test items were associated with Remember, Understand, Apply, Analyze, and Evaluate categories. 


\section{BIBLIOGRAPHY}

Anderson, et. al. (2001). A Taxonomyfor Learning, Teaching, and Assessing: ARevision of Bloom's Taxonomy of EducationalObjectives. New York, N.Y: Longman.

Ayvaci, \& Turkdogan. (2010). Analysing "Science and Technology Course Exam Questions" According to Revised Bloom Taxonomy. Retrieved from http://www.tused.org/internet/tused/sayilar/defaultarchive.asp?islem=git2\&id=184

Boyd, N. (2009). A Creative Writing Research Methodology.

Haryanti. (2006). Analisis Soal-Soal Biologi Kelas VII SMP Semester Gasal Pada Buku Pegangan Guru Se-Kabupaten Pati. Retrieved from http://digilib.unnes.ac.id/gsdl/collect/skripsi/archives/HASHc02f.dir/doc.pdf 